\title{
MEDIA ELEKTRONIK DAN DAKWAH ISLAM
}

\author{
Juniawati
}

\begin{abstract}
Abstrak
Media juga disebut sebagai "Media is the extensions of man", yakni media adalah perluasan dari ide, gagasan dan pikiran terhadap kenyataan sosial. Konsep yang dikemukakan Marshall McLuhan bahwa media adalah pesan itu sendiri (the medium is the message), dipahami bahwa media lebih dari sekedar wahana. dari aspek program, kelebihannya adalah sifatnya yang personal. Artinya pendengar dapat merasakan suasana akrab, sehingga mudah tersalurnya komunikasi. Oleh karena itu secara tidak langsung media berfungsi ganda, selain sumber informasi yang menyajikan apa yang terjadi, media khususnya cetak bisa mendidik masyarakat yang tidak terdidik. konsep yang dihadirkan dari media memenuhi selera pasar yakni masyarakat. Terutama dari segi kebutuhan informasi lokal dan daerah. Karena secara makro wacana dalam media massa menjadi alat konstruksi realitas sosial mengingat bahwa realitas sosial tidak berdiri sendiri tanpa kehadiran individu, baik di dalam maupun di luar realitas tersebut.
\end{abstract}

Kata Kunci: informasi, masyarakat, berita

\section{A. Pendahuluan}

Sejatinya kehadiran media hari ini diharapkan secara khusus dapat memberikan warna tersendiri bagi kehidupan umat Islam dalam pelbagai aspek. Sebab, harapan masyarakat demikian besar terhadap kehadiran media. Di tengah-tengah kehidupan yang hiruk-pikuk hari ini ditambah dengan masyarakat yang majemuk, tentunya media dapat membangun kekuatan masyarakat untuk bergerak membangun dirinya berkehidupan lebih maju dan lebih baik dalam segala bidang.

Harapan di atas tidaklah berlebihan, bila mengingat dengan kompisi umat Islam yang masih mendominasi dari umat beragama lainnya di ngeri ini. Hal ini lantaran media mampu menyebarluaskan berita dengan cepat, menembus ruang dan waktu, secara live atau recorded, onstage maupun broadcasted, hingga bahkan menembus tembok kamarkamar tidur keluarga yang tidak 
mungkin ditembus sendiri oleh individu.

Media juga bisa dikatakan sebagai "Penyedia Data lengkap" yang kehadirannya jadi kebutuhan yang kian siginifikan. Lebih lanjut aksi media lewat tampilannya yang berulangberulang dapat memberikan efek pengaruh terhadap masyarakat sebagai konsmen (baik individu, keluarga dstnya).

Dari aspek kemudahan media massa, salah satu kemudahan dari bentuk media massa khususnya cetak adalah dari segi bahasa. Selain bahasa media cetak adalah bahasa yang formal dan bahasa daerah (melayu), pada kolom tertentu, kalimatnya mudah dicerna dan terperinci; isi pesannya dapat dicerna berulang.

Karena itu, dari aspek pesan yang disajikan media massa, dalam pandangan Melvin De Fluer dan Sandra Ball Rokeach, (1988) apa yang disajikan tidak terlepas dari keadaan sekitar. Pesan yang disampaikan berdasarkan:

- Berdasarkan keadaan yang ada di masyarakat dunia.

- Sebagai perpanjangan lidah dari masyarakat (menjalankan fungsi kebebasan bersuara)
- Sebagai "Penyelamat" atau pengawal watchdog masyarakat

- Memperkenalkan kesenian dan hiburan (media entertaiment)

- Meingkatkan taraf, harkat dan martabat hidup masyarakat, baik ekonomi, politik dan sosial

Selain itu, konsep yang dihadirkan dari media memenuhi selera pasar yakni masyarakat. Terutama dari segi kebutuhan informasi lokal dan daerah. Karena secara makro wacana dalam media massa menjadi alat konstruksi realitas sosial mengingat bahwa realitas sosial tidak berdiri sendiri tanpa kehadiran individu, baik di dalam maupun di luar realitas tersebut (Fita Faturokhmah, 2009)

Hal ini menjadi lebih menarik ketika media massa melalui konten yang disajikannya mampu memberikan informasi yang akurat dan sedemikian dekat dengan keadaan, kebutuhan serta minat masyarakat setempat. Fungsi media semacam ini, dipandang McQuail (1987) tidak terlepas dari ciri khusus dari media massa sendiri yakni:

1. Mendistribusikan pengetahuan dalam wujud informasi, pandangan dan budaya.

2. Menyediakan saluran untuk menghubungkan orang tertentu 
dengan orang lain yakni dari pengirim ke penerima, dan dari khalayak kepada anggota khalayak lainnya.

3. Media menyelenggarakan sebagian besar kegiatannya dalam lingkungan publik.

Media massa menurut Atep Abdurofiq (2006) juga menyuguhkan peran sebagai penyeimbang, menjadi sarana yang bisa memediasi masyarakat dalam mengembangkan aspirasi dan partisipasi sekligus memperkuat percaya diri dan daya mampu masyarakat dalam mengakses perkembangan yang terjadi. Atep Abdurofiq (2006) malah melihat lebih jauh dan menyeluruh bahwa media massa tidak sekadar memberikan informasi tapi juga perekat persatuan dan kesatuan bangsa dalam rangka nation and character building.

Melalui media massa, aspek partisipasi masyarakat dalam memberikan sumbang saran dapat menciptakan kesadaran dan tanggungjawab individu dalam masyarakat, antar kelompok masyarakat, masyarakat dengan pemerintah maupun sebaliknya. Oleh itu, tidak salah apabila masyarakat menaruh harapan besar kepada media

\section{B. Keunggulan Media Elektronik Audio Visual}

Media, dalam bahasa latin Mediare yang berarti pengantara, alat penghubung atau alat yang digunakan. Media juga disebut sebagai "Media is the extensions of man", yakni media adalah perluasan dari ide, gagasan dan pikiran terhadap kenyataan sosial. Konsep yang dikemukakan Marshall McLuhan bahwa media adalah pesan itu sendiri (the medium is the message), dipahami bahwa media lebih dari sekedar wahana (Farid Hamid dan Heri Budianto, 2011)

Media massa terdiri atas dua kelompok besar yankni media cetak dan elektronik. Kedua spesifikasi itu masing-masing memiliki sifat dan kelebihan. Perbedaan itu meliputi komponen yang berada di dalamnya. Keunggulan media massa adalah merupakan jenis komunikasi yang ditujukan kepada sejumlah khalayak yang tersebar di bermacam penjuru lokasi. Bersifat heterogen, dan anonim. Melalui media massa, sajian pesan yang sama secara serentak bisa diterima dan sesaat (Rakhmat, seperti yang dikutip komala dalam Karlinah, dkk,1999).

Oleh karena itu secara tidak langsung media cetak berfungsi ganda, selain sumber informasi yang 
menyajikan apa yang terjadi, media massa khususnya cetak bisa mendidik masyarakat yang tidak terdidik, (Devito, 1997). Kegiatan ini dalam kaca mata media cetak bisa dalam bentuk feature, artikel,laporan dan karya jurnalistik lainnya, (Ardhana, 1995:26). Maka ada sedikit kekhasan dari model komunikasi media massa, yakni proses dengan pesan komunikasi massa mengalir adalah satu arah, (Devito, 1997).

Maksudnya, pesan yang mengalir ini dari sumber ke penerima tetapi jarang sekali dari penerima ke sumber. Dan, proses seleksinya adalah dua arah. Dimana sumber media menyeleksi kelompok yang akan menjadi sasaran pembaca dan penerima menyeleksi media yang akan mereka dengar/saksikan.

Sedangkan keunggulan untuk bentuk media elektronik seperti TV dalam skala jangka panjang, disebutkan Royono Praktikno (1982), sifat keunggulannya dengan media cetak nyaris sama, hanya penekanann pada bentuk gambar dan suara yang dapat didengar (ditanggap langsung). Sebab lain dikatakan Amri Jahi (1993), pemirsa siaran TV juga dapat mengambil guna sekalipun tidak membaca.
Siaran Televisi akan memudahkan penonton pemirsa, seperti dari segi format siaran yang diramu. Siaran Televisi bisa menyajikan hiburan, pendidikan dan hiburan sosial, ekonomi dan budaya yang menyangkut kehidupan masyarakat sehari-hari, Kesamaan inilah yang dinilai memiliki tujuan penyajian yang sama pada semua jenis media massa.

Menyambung sifat TV tadi, menurut tinjauan Onong U.Effendy (1981), tiada lain salah satu faktor utama pendukung TV adalah kecanggihan dari teknologi melalui gelombang elektromagnetis maupun lewat kabel-kabel (televison cable).

Sementara dari penyelenggaraan penyiaran radio, dari aspek program siaran, kelebihannya adalah sifatnya yang personal. Artinya pendengar dapat merasakan suasana akrab, sehingga mudah tersalurnya komunikasi. Kedua, imprehensif. Segala informasi selalu cakap, tepat dan jelas. Ketiga, siaran radio, bisa mengatasi buta huruf. Pendengar tidak dituntut haarus pandai baca-tulis. Dengan demikian, radio secara simultan bisa mendramatisir situasi pendengar dalam jarak jauh, sehingga pendengar dengan sadar menerima pesan atau informasi dengan mudah. 
Seperti Jalaludin Rakhmat (1995) menilai situasi pendengar sebagai suatu kelebihan yang dipertimbangkan, sebab proses persepsi diperoleh dengan mudah lewat pengalaman tentang objek, peristiwa/hubungan yang diperoleh dengan mengembangkan informasi dan menafsirkan pesan. Sebagaimana kita ketahui bahawa radio merupakan salah satu media eletronik yang murah, mudah (fortable) di bawa kemana-mana dan bahasa yang digunakan adalah bahasa telinga yang mudah dicerna dan dimengerti.

Kehadiran radio di tengahtengah masyarakat adalah sebagai jawaban kebutuhan masyarakat akan informasi dan hiburan. Aspek kecepatan medium jenis ini memang tidak terbantahkan sejak pra kemerdekaan hingga masa reformasi saat ini.

Radio menjadi sangat signifikan. Artinya, manakala konten yang disediakan radio menjadi alternatif jawaban dari permasalahan yang dihadapi masyarakat, menjadi pelepas lelah masyarakat di tengah rutinitas pekerjaan sehari-hari dan mampu menjadi penyedia informasi yang update dan tercepat bagi beberapa kalangan yang memilih informasi sebagai kebutuhan mendasar.
Radio menjadi pilihan tercepat dengan aktifitas keseharian masyarakat ketika radio ikut mengangkat kisi-kisi kehidupan masyarakat. Mulai dari pertanian, ekonomi, pendidikan, sosial dan budaya. Berangkat dari kearifan masyarakat di tingkat komunitas hingga masyarakat secara global (cross culture).

Maka pantas, ketika radio dikatakan memiliki kemampuan dari aspek komunikasi bermedia. Sebab sebagian besar kemampuan komunikasi dimiliki radio. Ini dapat dilihat pada bentuk atau jenis program yang diperdengarkan ke pendengar. Seperti, program monolog yang menerapkan komunikasi satu arah atau pada program perbincangan di radio dalam hal ini dikenal sebagai Talk Show, wawancara interaktif maupun program hiburan yang melaksanakan publik sphere sebagai orientasinya. Dan banyak lagi bentuk yang dijalankan medium radio.

Selain itu, tidak terkecuali juga bahwa medium ini juga sebagian menjalankan program kajian-kajian atau penelitian. Baik untuk mengukur salah satu aspek kehidupan masyarakat sampai pada mencari tahu apa yang menjadi keinginan masyarakat yang dapat diangkat oleh 
radio atau hanya untuk mengukur keberhasilan radio dari program siaran yang diciptakan. Oleh itu, wajar apabila banyak kelebihan yang dimainkan medium ini khususnya dalam membangun citra masyarakat dalam pelbagai aspek kehidupan.

\section{Radio: Model Dakwah Islam Masa kini}

1. Dakwah Islam

Dakwah adalah membawa seseorang dari satu sisi kepada sisi yang lain, sesuai dengan asal kata fi'il madinya Da'a yang mempunyai arti mengajak, memanggil, menyeru seseorang agar mengikutinya. Ali Mahfud menyebutkan dakwah sebagai bentuk motivasi mendorong umat manusia melakukan kebaikan dan mengikuti serta memerintahkan agar berbuat ma'ruf dan mencegah dari perbuatan munkar (Roudhonah, 2011).

Menurut Yusuf Qardhawi esensi dakwah adalah bermakna membangun gerakan yang akan membawa manusia ke jalan Islam yang meliputi aqidah dan syariah, dunia dan negara, mental dan kekuatan fisik, peradaban dan umat, kebudayaan dan politk serta jihad menegakkanya di kalangan umat Islam sendiri, agar terjadi sinkronisasi antara realitas kehidupan muslim dengan aqidahnya (Roudhonah, 2011)

Gerakan-gerakan dakwah Islam yang berada di masa sekarang, menjadi kacamata besar, bahwa dakwah Islam pada masa kini terus eksis dan terus berkembang, baik secara internal maupun eksternal. Secara internal, semakin banyaknya kesadaran umat Islam terhadap nasib agamanya sendiri. Adapun secara eksternal, banyaknya jumlah masyarakat di berbagai negara yang memeluk Islam setelah sebelumnya beragama lain.

Faktor yang membuat terjadinya peningkatan yang sangat signifikan terhadap perkembangan dakwah adalah adanya wadah dakwah yang siap meneruskan risalah Rasulullah dengan modelmodel dakwah yang mereka gunakan, sesuai dengan kekreatifan dan perkembangan zaman. Hal ini mengingat bahwa umat Islam sendiri dihadirkan ke muka bumi sebagai umat yang terbaik sebagaimana firman Allah dalam Ali-Imran:10:

"Kalian adalah umat yang terbaik dilahirkan untuk manusia, menyuruh kepada yang makruf, 
dan mencegah dari yang mungkar, dan beriman kepada Allah"

Radio, menjadi model dakwah yang ampuh untuk digunakan berdakwah. Radio mempunyai pengaruh besar, selain keterpikatan suara penyiar, adapula sajian-sajian mata acara yang luar biasa kreatif. Disini dai mempunyai kesempatan besar untuk menyampaikan sebuah risalah, disamping karena jangkauan yang luas, sang dai juga tidak kerepotan untuk mengumpulkan mad'uh. Mad'u cukup bergabung dengan frekuensi radio.

Keistimewaan radio yaitu radio merupakan metode komunikasi audio visual yang sangat besar pengaruhnya. Karena radio ini adalah alat yang melayani masyarakat secara instan untuk mendengarkan sebuah informasi terkini, terutama tentang dunia Islam.

Selain itu kesempatan besar bagi dakwah Islam, untuk menggunakan radio sebagai langkah elternatif untuk menyampaikan ajaran syariat Islam. Karena dakwah melalui radio prosesnya lebih efektif dari pada bertatapan secara langsung dengan mad'u.
2. Jurnalisme Dakwah

Islam adalah agama dakwah. Umat Islam berkewajiban melaksanakan ajaran Islam dalam keseharian hidupnya dan harus menyampaikan (tabligh) atau mendakwahkan kebenaran ajaran Islam terhadap orang lain. Radio menjadi alat instan yang boleh dipakai oleh umat Islam untuk berdakwah. Radio juga menjadi solusi baik, ketika seseorang tidak punya keberanian berdakwah di depan umum.

Seruan dakwah itu ditujukkan untuk semua profesi dan profesi yang paing mungkin melakukannya dengan sasaran massa adalah profesi jurnalis. Melalui Radio, seorang jurnalis dapat mengintruksi realitas yang ada di masyarakat. Kerja jurnilis tidak sekadar menyampaikan informasi melalui berita yang dihasilkannya, melainkan mampu membentuk opini masyarakat melalui karya tulisnya, dan media yang mejadi penghubung untuk kerja-kerja dalah melalui media. Karena itu, aktifitas dakwah dalam hal ini tidak terbatas. DR. Fuad dalam Asep Saiful Romli (2004) mengemukakan bahwa aktifitas dakwah sangat luas dan 
untuk melihat ini dapat dilihat pada

4 aktifitas utama:

a. Mengingatkan orang akan nilai kebenaran dan keadilan dengan lisan

b. Mengkomunikasikan prinsip Islam melalui karya tulisnya

c. Memberikan contoh keteladanan akan perilaku akhlak yang baik

d. Bertindak tegas dengan kemampuan fisik, harta dan jiwanya dalam menegakkan prinsip ilahi

Pertanyaannya, mengapa memilih media elektronik? Berdasarkan dari beberapa kenyataan bahwa pertumbuhan industri media elektronik seperti radio, banyak penyelenggara penyiaran yang terjun di bisnis ini. Ini terlihat secara kuantitas maupun jumlah iklan yang dicapai oleh stasiun radio. Menurut Agus Sudibyo ( 2004) bahwa pendapatan iklan radio di negara maju seperti Amerika Serikat, Inggris, Swedia dan Jerman berkisar antara 10-15 $\%$ dari pendapat iklan nasional. Sementara di beberapa negara Asia sebagian menjadikan media elektronik sebagai kekuatan dalam meraih selera masyarakat. Seperti Radio Philifina yang mana capaian iklannya $20 \%$ dan kehadirannya lebih dulu berkembang dari Indonesia, Agus Sudibyo ( 2004).

Terkait dengan pertanyaan di atas, tak pelak membuka mata kita bahwa media elektronik sangat populer di kalangan masyarakat dan ini suatu ajang yang sangat potensial untuk menyampaikan pesan-pesan Islam masa kini. Seperti menurut Fatmawati ade Sofyan (2006) Dakwah kontemporer adalah metode yang digunakan para da'i adalah lebih variatif mengikut keadaan zaman. Dalamhal ini dakwah melalui media merupakan bagian daripada metode tersebut. Maka itu kemasan yang dibuat mesti mengikuti keadaan trend media baik itu media cetak maupun elektronik, iaitu mesti lebih aktual, faktual dan kontekstual. Hal ini dimaksudkan untuk menyakinkan khalayak.

Bagaimana dengan media elektronik di Indonesia? Di Indonesia, tak kalah ketinggalan bahwa kecenderungan naiknya industri penyiaran misalnya radio dalam hasil rapat Paripurna PRSSNI tahun 2003 menyebutkan bahwa dalam kurun waktu 10 tahun yakni tahun 1986-2002 belanja iklan radio mengalami peningkatan yang sangat signifikan yakni 8 kali lipat 
dari Rp. 23 Milyar menjadi Rp. 189

Milyar.

\section{Tabel Belanja Iklan Radio di Indonesia}

\begin{tabular}{|c|c|c|}
\hline No & $\begin{array}{l}\text { Belanja Iklan } \\
\text { dalam Tahun }\end{array}$ & $\begin{array}{c}\text { Belanja Iklan dalam } \\
\text { Rupiah }\end{array}$ \\
\hline 1 & 1986 & Rp. 23 Milyar \\
\hline 2 & 1987 & Rp. 32 Milyar \\
\hline 3 & 1988 & Rp. 38 Milyar \\
\hline 4 & 1989 & Rp. 38 Milyar \\
\hline 5 & 1990 & Rp. 105 Milyar \\
\hline 6 & 1991 & Rp. 105 Milyar \\
\hline 7 & 1992 & Rp. 100 Milyar \\
\hline 8 & 1993 & Rp. 113 Milyar \\
\hline 9 & 1994 & Rp. 139 Milyar \\
\hline 10 & 1995 & Rp. 170 Milyar \\
\hline 11 & 1996 & Rp. 189 Milyar \\
\hline 12 & 1997 & Rp. 206 Milyar \\
\hline 13 & 1998 & Rp. 136 Milyar \\
\hline 14 & 1999 & Rp. 187 Milyar \\
\hline 16 & 2000 & Rp. 257 Milyar \\
\hline 17 & 2001 & Rp. 341 Milyar \\
\hline 18 & 2002 & Rp. 658 Milyar \\
\hline
\end{tabular}

Sumber: Agus Sudibyo, ( 2004). Ekonomi Media Penyiaran.

Berdasarkan pada kenyataan di atas sangat jelas bahwa, pendengar radio di Indonesia yang tentu saja adalah masyarakat dari pelbagai etnis dan budaya ini sangat memerlukan penyiaran radio.

Bicara masyarakat Indonesia sebagai konsumen dari program siaran radio tnetu saja tidak lepas dari umat Islam yang secara kapasitas menduduki jumlah tertinggi dari umat lainnya. Hal ini kemudian menjadi perhatian yang cukup penting bagi pembinaan potensi umat khususnya di bidang ini.

Media elektronik sudah tidak salah lagi jika menjadi media Dakwah Islam kepada masyarakat luas di semua negara. Jika di beberapa negara Asia sebagian menjadi radio sebagai suatu strategi Dakwah yang terkini dalam mendekatkan Ajaran Islam dengan umatnya. Ini disebab tingginya mobilisasi kehidupan masyarakat menjadikan radio mesti mengikuti lajunya kebutuhan masyarakat terhadap informasi maupun hiburan ke-Islaman. Oleh itu, dengan kemudahan radio mobile yang melekat pada alat-alat eletronik seperti Handfhone, ataupun yang tersedia pada kendaraan roda empat hingga kepada media (digital Ccyberspace) yang disebut-sebut sebagai gaya dari masyarakat baru era ini yang membuka peluang manusia saling bertemu dan berinteraksi di dunia maya. Di Indonesia juga tidak ketinggalan. Misalkan saja, era elektronik memadupadankan siarannya lebih cepat lagi dengan fasilitas internet 
begitu pula dengan radio (radio streaming).

Kemudahan media ini memberi manfaat pada siaransiaran radio nasional yang tersebar di tiap provinsi negeri ini menyediakan konten siaran bertemakan nilai-nilai ajaran Islam. Mengangkat sisi kehidupan masyarakat mulai dari tingkat paling bawah hingga gambaran masyarakat menengah ke atas, dengan memasukkan prinsip-prinsip akidah, ibadah dan muamalah.

Ini semakin meyakinkan kita bahwa tidak menutup kemungkinan apabila, dari pihak owner maupun dari struktur managemen stasiun radio yang ada dipengaruhi oleh Sumber Daya Manusianya (SDM) nya yang beragama Islam.

Ini belum termasuk radio yang memang secara penuh memuat program ke-Islaman dengan segmentasinya umat Islam. Belum lagi secara hitung-hitungan, keberadaan radio komunitas yang tersebar di sebagian besar Kabupaten dan kota di Indonesia termasuk di Perguruan Tinggi atau radio yang bersiaran secara ilegal. Tentu jumlah ini tidak mustahil dijalankan oleh umat Islam.
Dari keadaan ini, terlihat dimensi kerisalahan Dakwah menyentuh pada praktek hidup masyarakat dalam berbagai situasi dan senantiasa relefan dengan zamannya. Dengan kata lain, agama Islam mempunyai motivasi yang kuat dalam usaha mewujudkan dan membina masyarakat adil dan makmur yang merata material dan spiritual. Dan media merupakan alat yang ampuh dalam menggelorakan semangat masyarakat dalam kehidupannya.

Dan agama Islam dengan Qur'an sebagai motor kehidupan umat dapat memberi bentuk kepada arti dan kualitas hidup sebagaimana yang termaktub dalam (Q.S.Ibrahim /14 : 1) bahwa Al-qur'an sebagai pegangan umat Islam menjadi petunjuk kepada jalan terang benderang. Maka itu, cita-cita ini memang dapat ditempuh melalui berbagai cara dan kegiatan seperti melalui media elektronik.

Tentu juga kegiatan ini tidak lepas dari tujuan bahwa semua usaha ini merupakan sebagai jembatan manusia mencapai jalan hidup yang membahagiakan dan mensejahterakan dsbnya (lihat QS: Al-Anbiya:107). 
Untuk di Kalbar bisa dilihat dengan merebaknya jaringan sambungan atau dengan dipasangnya bantuan satuan transmisi khusunya pemancar di daerah semakin banyak. Masyarakat penyiaran di daerah ini semakin melirik media audio visual baik itu Televisi maupun radio sebagai lahan industri baru yang dibutuhkan masyarakat.

Penyiaran radio di Kalimantan Barat sebagai institusi sosial juga ikut meramaikan ruang udara di daerah ini. Tidak hanya bersiaran dengan konten umum juga melainkan menyiarkan program keIslaman yang sarat dengan informasi ke-Islam. Seperti pada stasiun radio swasta yang berkisar 24 stasiun radio menunjukkan bahwa kegiatan penyiaran di daerah ini juga memasukkan program agama Islam sebagai muatan siarannya (Tesis Juniawati 2007).

Meski stasiun radio swasta tidak menyebutkan secara khusus nama program agama Islam, ini karena stasiun tersebut di bawah kepemilikan agama nasrani namun secara substansi nilai-nilai ajaran Islam muncul dalam acara tersebut. Selain itu, program agama Islam yang tidak disebutkan nama program siarannya namun program agama Islam masuk dalam program siaran agama. Presentase program siaran agama secara umum pada masing-masing radio yang ada di Kalbar terbilang $6.3 \%$ (PRSSNI : 2006); Juniawati (2007).

Sementara untuk Televisi lokal yang wujud di Kalbar hingga kini, menurut KPID Kalbar (2008) selain TVRI Pontianak, terdapat 4 Televisi Swasta lainnya yang telah mendapat ijin resmi bersiaran yakni KCTV, Ruai TV, MKTV dan Pontianak TV (tabel 3). Peluang inilah yang semestinya diberi perhatian oleh umat Islam demi kemajuan umat Islam itu sendiri.

Dari beberapa siaran yang mengacu pada program siaran monolog ceramah satu arah (one way communication) yang ada di stasiun radio swasta tahun 2006, cukup memberikan waktu yang cukup panjang bagi satu mata acara siaran yakni berkisar 30 hingga 60 menit. Untuk format siaran yang berbentuk berbentuk talk show ataupun interaktif melalui telpon dan sms serta email juga menjadi bagian dari metode siaran yang diterapkan oleh radio swasta. 


\section{Penyiar Sebagai Ujung Tombak Dakwah Islam}

Dalam satu sistem
penyelenggaraan penyiaran baik
Televisi maupun radio tentu
memasukkan penyiar sebagai suatu
unsur yang membantu terlaksananya
penyiaran. Dalam kapasistasnya
menjembatani masyarakat sebagai
pendengar dan radio sebagai alat
komunikasi tentu saja bukan pekerjaan
mudah. Terlebih jika hal ini disanding
dengan pesatnya persaingan industri
penyiaran. Butuh kemampuan yang
mumpuni dalam membawakan suatu
program siaran.

Terlepas dari apa konten yang menjadi bidikan media, penyiar pada umumnya memiliki kemampuan teoritis maupun praktis (lihat Asep Kusnawan 2004; Munir dan Wahyu Ilaihi. 2009). Selain itu, daya saing lembaga penyelenggara penyiaran dan penyiar sebagai ujung tombak stasiun ini juga yang kemudian membawa seorang penyiar dapat membawanya menjadi publik figur.

Untuk menghadapi daya saing yang semakin tinggi ini, maka seorang presenter Televisi mesti memperhatikan hal-hal yang terkait dengan kerja penyiar secara profesional dan handal pertama sekali yang mesti diperhatikan oleh penyiar secara umum adalah memiliki rasa atau bersikap informatif, objektif, akurat, jujur, adil dan menghibur. Penyiar sebagai komunikator memegang kuasa penuh ketika berada di depan Mic/ di depan penonton. Apabila penyiar tidak mempunyai persiapan yang memadai alias miskin pengetahuan mengenai dunia penyiaran -dunia studio siaran, maka akan berpengaruh besar terhadap pendengar. Sebab bahasa dan penguasaan bersiaran yang lemah dan monoton dan membosankan. Ini dikarenakan prinsip kerja baik Televisi maupun radio sepenuhnya mengandalkan oral communication.

Teddy Respisari Pane (2004) menyarankan penyiar harus menyampaikan pesan secara efektif, dengan kata lain, penyiar memindahkan emosi yang sesuai dengan naskah -semangat, serius, atau ceria - tanpa ragu-ragu dan dengan cara persuasif. Dengan cara ini akan memberikan variasi serta interpretasi kepada pendengar. Karena itu, seluruh anggota tubuh terutama yang terkait dengan gaya atau gerakan tubuh (gesture) mesti menyatu dengan alat siaran agar pelaksanaan siaran dapat menyatu dan berjalan lancar dan tidak berdiri sendiri-sendiri 
Hal senada juga layak untuk diperhatikan yakni dari Hoyyima Khoiri (2010) agar penyiar mengenali benar kerja yang diembannya seperti berikut ini:

1. Kenali diri, gali kemampuan yang terpendam

2. Tentukan karakter agar mudah dikenal

3. Jaga sikap agar disegani

4. Mengatur waktu, mengendalikan rintangan

5. Kembangkan jaringan untuk menemukan keuntungan

Saran berikutnya untuk penyiar radio seperti dari Hoyyima Khoir (2010), ada beberapa tips jitu menjadi presenter radio:

1. Selalu mencintai "Mic"

2. Mempunyai wawasan yang luas

3. Tahu pasti isi acara yang dibawakan

4. Pahami gaya siaran khas radio tempat bekerja

5. Mempunyai pergaulan yang luas

6. Update tentang lagu-lagu

7. Menjaga kualitas suara (Vocal)

8. Think out of the box

9. Tetap semangat

Banyak lagi bahan rujukan yang mengarahkan seseorang bagaimana menjadi penyiar yang dapat di adopsi penyiar dengan program siaran agama Islamnya tanpa harus meninggalkan upaya mengenal siapa masyarakat yang mendengarkan acaranya.

Oleh itu, kecakapan penyiar atau pembawa acara yang "ready to work" atau siap pakai memang dipertaruhkan sekaligus jadi kemestian oleh stasiun radio maupun televisi. Dan, kenyataan di lapangan memperlihatkan bahwa penyiar radio sebagian besar beragama Islam. Karenanya, ini tentu sedikit banyak memberi pengaruh pada pendengar, yang notabenenya juga adalah umat Islam. Bagaimana seorang penyiar dapat memberikan contoh lewat acara yang dibawanya, lewat gayanya bersiaran. Sehingga apa yang ditampilkan seorang penyiar dari balik studio ini bisa membawa pengaruh yang baik kepada masyarakat.

Jauh sebelum itu, yang paling utama dari seorang penyiar tentunya adalah wawasan yang kemampuan berkomunikasi dengan masyarakat (baca: pendengar). Kemampuan berbicara di udara tanpa kehadiran fisik pendengar dan menempatkan pendengar sebagai teman atau sahabat merupakan kunci penyiar meraih hati pendengarnya.

Kembali dalam konteks Dakwah, kegiatan penyiar yang berbicara di depan mikrofon ini terkait dengan cara kita berkomunikasi. Sebagaimana al- 
qur'an menegaskan, ada pembicaraan yang baik, sopan santun, lemah lembut (qaulan syadidan, qaulan baligho, qaulan kariman, qaulan maisuran dan qaulan layyinan) sehingga bisa menyejukkan hati penerima pesan atau pendengar. Berikut beberapa surat dalam Alqur'an yang mengisyaratkan hal tersebut:

- Al-qur'an surat Al-Isra ayat 23 (Qaulan Karima)

- Al-qur'an surat An-Nisa ayat 63 (Qaulan Baligha)

- Al-qur'an surat Thaha ayat 44 (Qaulan Layyina)

Selain itu, penyiar sebagai penyambung lidah masyarakat khususnya umat Islam, di tengahtengah arus globalisasi informasi dan munculnya berbagai gerakan yang terkadang bertentangan dengan nilainilai Islam, secara tidak langsung penyiar dituntut untuk mengenali kondisi masyarakat yang terjadi saat ini sehingga dalam berpijak dan bertindak mengutamakan nilai-nilai moral dan mampu menyentuh dan mnyejukkan hati agar dakwah yang disampaikan oleh penyiar melalui profesinya dapat diterima, sehingga membawa perubahan kepada pendengar yang notabene umat Islam.
Pendekatan di atas patut dikuasai, mengingat keberadaan masyarakat sebagai pendengar yang beragam. Keadaan pendidikan, sosial budayanyapun berbeda. Karena hal ini juga menjadi tantangan bagi seseorang dalam menyampaikan dakwahnya. Dengan demikian, benang merah kedudukan sebagai penyiar yang merupakan bagian dari masyarakat dan memiliki peluang menjalankan profesinya, menjadi salah satu cara bagi pelaksanaan Dakwah Islam.

\section{E. Penutup}

Mengingat media mempunyai peranan dan pengaruh yang besar baik dan buruk- kepada perkembangan dunia, terutama dalam hal ini umat Islam maka perlu usaha untuk menaklukkan media dengan cara:

1. Media yang Islami harus bersifat proaktif, interaktif, informatif, kompetitif, kontemporer dalam menyampaikan pesan dakwah.

2. Program siaran keagamaan melalui media televisi dan radio dapat menjangkau seluruh lapisan masyarakat serta dapat menembus ruang dan waktu tanpa batas, sekiranya format ini perlu dikemas dengan baik bagaimana suatu 
siaran keagamaan atau dakwah menjadi rujukan utama masyarakat sehingga dapat menyenangkan dan mendatangkan manfaat dan memiliki daya tarik tersendiri

3. Sumber daya manusia (SDM) umat Islam mesti makin melirik peluang dakwah lewat media elektronik dan menjadikannya sebagai bidang garap yang potensial bagi pengembangan kualitas umat Islam

\section{F. Daftar Pustaka}

Agus Sudibyo, 2004. Ekonomi Media Penyiaran Agus Sudibyo. Jogjakarta: LkiS

Jahi, Amri, 1993. Komunikasi Massa dan Perdesaan Di Negara-negara Ketiga. Gamedia Utama : Jakarta

Asep Syamsul M. Romli. 2004. Broadcast journalism: panduan menjadi penyiar, reporter, dan scriptwriter, penerbit nuansa Cendikia. Bandung.

Atep Abdurofiq. 2006. Peran media massa di Indonesia sebagai Institusi Penyeimbang. DIm Jurnal Dakwah Vol VIII No.2. Jakarta: UIN Syarif Hidayatullah

Ball Rokeach dan DeFluer (1988) (Terj). Teori Komunikasi Massa. Kuala Lumpur Malaysia: Dewan Bahasa dan Pustaka Kementerian Pendidikan Malaysia
Farid Hamid dan Heri Budianto (editor).2011. IImu Komunikasi sekarang dan Tantangan Masa Depan.Jakarta: Kencana Prenada Media Group

Fatmawati ade Sofyan. 2006. Dakwah di Televisi: Analisis Terhadap mimbar Da'i dan Da'iah TPI dalam perspektif Dakwah. Dlm.Jurnal Dakwah Vol VIII No.2. Jakarta: UIN Syarif Hidayatullah

Fita Faturokhmah, 2009. Propaganda Media dalam Mewacanakan Komunitas Agama Jemaat Ahmadiyah Indonesia (JAl). DIm.Jurnal Dakwah Vol VIII No.2. Jakarta: UIN Syarif Hidayatullah Hoyyima Khoir. 2010. Cara Mudah Menjadi Presenter Televisi dan Radio. Jogjakarta: DIVA Press Juniawati. $2007 . \quad$ Penyiaran pembangunan: kedudukan dan pengamalannya dalam sistem penyiaran di kalimantan barat tahun 1994 hingga 2003. Tesis, UKM. Bangi

Pratikno Riyono, 1982. Komunikasi Pemabungan. Bandung.

Rahmad, Jalaluddin. 1995. Metode Penelitian Komunikasi. Bandung: CV. Remaja Karya

Roudhonah, 2011. Urgensi Komunikasi dan Kebudayaan dalam Keberhasilan Dakwah. Jakarta: UIN 
Syarif Hidayatullah. Jurnal Dakwah.

Vol XV. NO.1

Teddy Respisari Pane. 2004. Speak Out.

Panduan Praktis dan Jitu Memasuki

Dunia Broadcasting. Jakarta: PT

Gramedia Pustaka Utama

Ujana Efendy, 2001. IImu Komunikasi

Teori dan Praktek. Bandung:

Remaja Rosda Karya

-----------, $1981 . \quad$ Dinamika

Kuminkasi. Bandung: Remaja

Rosdakarya 